\title{
Screening of Antibacterial and Anticancer Activity of Soft Corals from Togean Islands, Indonesia
}

\author{
Muhammad Sulaiman Zubair ${ }^{1 *}$, Subehan Lallo² ${ }^{2}$ Rusmianti ${ }^{1}$, Arsa Wahyu \\ Nugrahani $^{1}$, Ibrahim Jantan ${ }^{3}$
}

\begin{abstract}
1Department of Pharmacy, Faculty of Sciences, Tadulako University, Kampus Bumi Tadulako, 94118, Palu, Indonesia;

2Faculty of Pharmacy, Hasanuddin University, 90245, Makassar, Indonesia, 3School of Pharmacy, Taylor's University, Lakeside Campus, 1 Jalan Taylors, 47500

Subang Jaya, Selangor, Malaysia
\end{abstract}

Submitted: $22-10-2018$

Revised: $12-11-2018$

Accepted: $17-12-2018$

*Corresponding author Muhammad Sulaiman Zubair

Email:

sulaiman_zubair80

@yahoo.co.id

\begin{abstract}
Soft corals (Octocorallia, Alcyonaceae) have been reported to possess diverse biological activities and unique structural chemistry. This study aims to screen the potential antibacterial and anticancer activity of some soft corals collected from Togean Islands, Central Sulawesi, Indonesia. They were Lobophytum $s p$, Sarcophyton sp, Sinularia $s p$ 1, and Sinularia $s p 2$. All dried coral materials were extracted for $3 \times 24 \mathrm{~h}$ by maceration method using methanol and then evaporated by rotary evaporator to obtain viscous extracts. The determination of antibacterial activity had been performed by well agar diffusion method against Staphylococcus aureus and Escherichia coli. Meanwhile, the cytotoxic activity was performed by MTT method, followed by apoptosis annexin V-FTIC assay. Identification for the presence of terpenoids was performed by $\mathrm{p}$-anisaldehyde-sulphuric acid spraying reagent on thin layer chromatography (TLC). Sinularia $s p 2$ extract have strongly inhibited $S$. aureus and E.coli with the diameter of inhibition of $15.80 \mathrm{~mm}$ and $15.73 \mathrm{~mm}$, respectively. Moreover, Sinularia sp 2 extract possessed also cytotoxic activity against human breast adenocarcinoma (MCF-7) and colorectal carcinoma (HCT-116) with the IC 50 of 46.807 and $47.186 \mu \mathrm{g} / \mathrm{mL}$, respectively. Extract Sinularia sp 1 was found to have strongest cytotoxicity on human colon colorectal carcinoma (HCT-116) with the $\mathrm{IC}_{50}$ of $<1.505 \mathrm{\mu g} / \mathrm{mL}$. Annexin V-FTIC assay clearly exhibited that the apoptosis mechanism is proposed by the extracts of Sinularia sp 1 and Sinularia sp 2. Terpenoids were identified on both extracts suggesting for further purification and isolation for the bioactive terpenoid compounds.
\end{abstract}

Key words: Softcorals, Togean Islands, anti-cancer, antibacterial

\section{INTRODUCTION}

Infection diseases caused by bacteria, and resistance of antibiotics and anticancer drugs are still become health problem in the worldwide. There are many studies in this field searching for the new source of antibiotic and anticancer drugs, especially from marine (Afifi et al., 2016). It is because the marine organisms have been reported progressively in the past 50 year that they possessed diverse unique chemical structure of new bioactive compounds (Abou El-Ezz et al., 2013). Among marine organisms, marine invertebrates are the most producers of marine natural product. Soft corals (octocorallia, Alcyonaceae) have been studied well and they become promising sources of new anti bacteria and anticancer agents (Coll, 1992). Most of the reported compounds are sesquiterpenes, diterpenes, polyhydroxylated steroids, and polyamine compounds (Blunt et al., 2016; Chen et al., 2012).

Indonesian coast is one of the richest biodiversity for marine organisms in the ocean. There are more than 20 publications on the bioactive compounds from Indonesian soft corals (Cladiella sp, Lobophytum sp, Sinularia sp) have been reported during 1997 - 2004. These bioactive compounds showed various pharmacological activities such as antimicrobial, anti-inflammatory and cytotoxic (Putra et al., 2016). Previously, our study on soft corals of Sarcophyton trocheliphorum and lobophytum sp have found numerous secondary metabolites possessing antibacterial and antitumor activities (Zubair et al., 2016; Al Footy et al, 
2016). In continuing our focus research on marine organism, particularly from Indonesian marine, our study now starting on soft corals collected off Togean Islands, located in Tojo Una-una, Central Sulawesi. There are four collected corals : Lobophytum sp, Sarcophyton sp, Sinularia $s p$ 1, and Sinularia sp 2. This study continued by screening assay for antibacterial and cytotoxic activity to find the most potential one that could be used as antibacterial and anticancer drugs in the future. To the best of our knowledge, this is the first report regarding antibacterial and anticancer of soft corals collected from Togean islands, Indonesia

\section{MATERIAL AND METHODS Material}

All samples of soft corals were collected in January 2017 on Togean Island, Tojo Unauna, Indonesia at a depth of $5-10 \mathrm{~m}$ and identified at UPT. Sumber Daya Hayati, Tadulako University. A voucher sample was deposited at Laboratory of Pharmacognosy and Phytochemistry, Department of Pharmacy, Tadulako University

\section{Extraction}

Material of soft corals were washed with water and dried at room temperature. Then, they were minced and repeatedly extracted for $3-5 \times 24 \mathrm{~h}$ by maceration method with methanol as a solvent at room temperature. Then each obtained extracts were evaporated by using rotary evaporator to reach a viscous extracts. Each of extracts was subjected for further analysis.

\section{Antibacterial Screening}

Antibacterial screening was performed against two types of bacteria : Staphylococcus aureus and Eschericbia coli by using agar well diffusion method (Limberger et al., 2001). Briefly, $0.1 \mathrm{~mL}$ of suspended bacterium in sterile medium $\left(1.5 \times 10^{8} \mathrm{CFU} / \mathrm{mL}\right)$ was spread on nutrien agar media. Then $50 \mu \mathrm{L}$ of each sample $(1000,500$ and $250 \mathrm{mg} / \mathrm{mL})$ was poured into the wells (6-mm diameter). All plates were left for $1 \mathrm{~h}$ at $48^{\circ} \mathrm{C}$ and then incubated for $24 \mathrm{~h}$ at $37^{\circ} \mathrm{C}$ for bacteria. Inhibition zone diameters formed around the well were measured and the mean diameter of three replicates was calculated. DMSO was used as a negative control and chloramphenicol as a positive control.

\section{Cytotoxic Activity}

Cytotoxic activity was applied on human breast adenocarcinoma (MCF-7), human colon colorectal carcinoma (HCT-116), NDHF normal cells and CDD-118 normal cell lines by MTT method as described in our previous study (Zubair et al., 2016). Doxorubicin and fluorouracil were used as a positive standard anticancer drug. The stock samples were diluted with RPMI-1640 medium to desired concentrations of $62.5,125,250,500$ and $1000 \mu \mathrm{g} / \mathrm{mL}$. The final concentration of dimethylsulphoxide (DMSO) in each sample was $1 \% \mathrm{v} / \mathrm{v}$. The cancer cells were batch cultured for $10 \mathrm{~d}$, then seeded in 96 well plates of $1 \times 10^{4}$ cells/well in fresh complete growth medium in 96-well microtiter plastic plates at $37^{\circ} \mathrm{C}$ for $24 \mathrm{~h}$ under $5 \% \mathrm{CO} 2$ using a water jacketed carbon dioxide incubator (Cel Culture, Esco Medical ApS, Denmark). The medium (without serum) was added and cells were incubated either alone (negative control) or with different concentrations of sample. After $24 \mathrm{~h}$ and $48 \mathrm{~h}$ of incubation, cells were added with $10 \mu \mathrm{L} /$ well of MTT $(5 \mathrm{mg} / \mathrm{mL})$ and incubated for $4 \mathrm{~h}$ in incubator at $37^{\circ} \mathrm{C}$ in $5 \%$ $\mathrm{CO} 2$ humidified atmosphere. The reaction was stopped by $100 \mu \mathrm{L}$ dimethylsulfoxide (DMSO). The plate was then incubated for $15 \mathrm{~min}$. The absorbance of each well was read at $550 \mathrm{~nm}$ wavelength in Elisa Reader (Infinite M200 pro NanoQuant, Tecan, Switzerland), using wells without cells as blanks. All experiments were performed in triplicate. The effect of compounds on proliferation of cancer cells was expressed as the \% cytoviability, using the following formula:

$\%$ Cytoviability $=$ Absorbance of treated cells/Absorbance of untreated cells (negative control) $\times 100 \%$

The $\mathrm{IC}_{50}$ calculation was done statistically by probit analysis using SPSS 17.0 (SPSS.Inc, Chicago IL, USA), in which the series of doseresponse data and the percentage of cytoviability were plotted together. 
Table I. Antibacterial activity of Togean islands soft corals

\begin{tabular}{ccc}
\hline \multirow{2}{*}{ Soft corals } & \multicolumn{2}{c}{ Mean Diameter of Inhibition Zone (mm) at 1000mg/mL } \\
\cline { 2 - 3 } & Staphylococcus aureus & Escherichia coli \\
\hline Lobophytum sp & - & - \\
Sarcophyton sp & $12.75 \pm 0.08$ & $12.25 \pm 0.50$ \\
Sinularia sp 1 & $12.36 \pm 0.46$ & $13.32 \pm 0.16$ \\
Sinularia sp 2 & $15.80 \pm 0.30$ & $15.73 \pm 0.41$ \\
Chloramphenicol & $28.28 \pm 0.50$ & $26.91 \pm 0.40$ \\
\hline
\end{tabular}

$\mathrm{a}=$ Chloramphenicol was tested at $1 \mathrm{mg} / \mathrm{mL}$

Table II. Cytotoxic activity of Togean islands soft corals

\begin{tabular}{lcccccc}
\hline \multirow{2}{*}{ Soft corals } & \multicolumn{6}{c}{ Inhibition Concentration, $\mathbf{I C}_{50}(\boldsymbol{\mu g} / \mathbf{m L})$} \\
\cline { 2 - 6 } & \multicolumn{7}{c}{ MCF-7 } & \multicolumn{6}{c}{ HCT-116 } & CDD & NDHF \\
\hline & $24 \mathrm{~h}$ & $48 \mathrm{~h}$ & $24 \mathrm{~h}$ & $48 \mathrm{~h}$ & $24 \mathrm{~h}$ & $24 \mathrm{~h}$ \\
Lobophytum sp & 91.415 & 92.116 & 162.978 & 162.978 & ND & ND \\
Sarcophyton sp & 168.824 & 260.557 & 264.783 & 264.783 & ND & ND \\
Sinularia sp 1 & 43.315 & 24.02 & 1.505 & $<1.505$ & 1.901 & Non Detectable* \\
Sinularia sp 2 & 52.337 & 46.807 & 47.186 & 47.186 & 166.029 & 143.616 \\
Doxorubicin & 0.024 & ND & ND & ND & ND & ND \\
Fluorouracil & ND & ND & 8.915 & ND & ND & ND \\
\hline
\end{tabular}

$\mathrm{ND}=$ Not determined $*$ Non Detectable $=$ sample used is range $1000-63.5 \mu \mathrm{g} / \mathrm{mL}$ and percentage of died cells obtained is around $93-94 \%, \mathrm{IC}_{50}$ cannot be calculated

\section{Annexin V-FITC apoptosis assay}

Annexin V-FITC apoptosis assay of cancer cells (MCF-7 and HCT-116) were seeded as described above and then incubated with different treatments for 24h. Cells were harvested, washed twice with PBS and centrifuged. In brief, $1 \times 10^{5}$ of cells were treated with annexin V-FITC and propidium iodide (PI) using the apoptosis detection kit (BD Biosciences, San Jose, CA) according to the manufacturer's protocol. Annexin V-FITC and PI binding were analyzed by flow cytometry on FACScanto II (BD Biosciences, San Jose, CA) without gating restrictions using 10.000 cells. Data were collected using logarithmic amplification of both the FL1 (FITC-A) and the FL2 (PI-A) channels. Quadrant analysis of coordinate dot plots was performed with CellQuest software. Unstained cells were used to adjust the photomultiplier voltage and for compensation setting adjustment to eliminate spectral overlap between the FL1 and the FL2 signals.

\section{Identification of terpenoids}

The presence of terpenoids was identifed by using $\mathrm{p}$-anisaldehyde-sulphuric acid spraying reagent on thin layer chromatography (TLC).

\section{RESULT AND DISCUSSION}

The aims of this study is to screen for the most potent antibacterial and anticancer activity of four soft corals collected from Togean Islands. The four soft corals was identified as Lobophytum sp, Sarcophyton sp, Sinularia sp 1, and Sinularia sp 2 (Figure 1) Meanwhile, the result of antibacterial and anticancer activity (Table I and II).

Antibacterial test was performed by well agar diffusion method. Staphylococcus aureus and Escherichia coli was chosen as tested bacteria as the representative of gram positive and gram negative bacteria. In table I only three samples have inhibition to Staphylococcus aureus and Escherichia coli, means that these samples have broad spectrum of antibacterial activity. Sinularia sp 2 are the most potent with the 

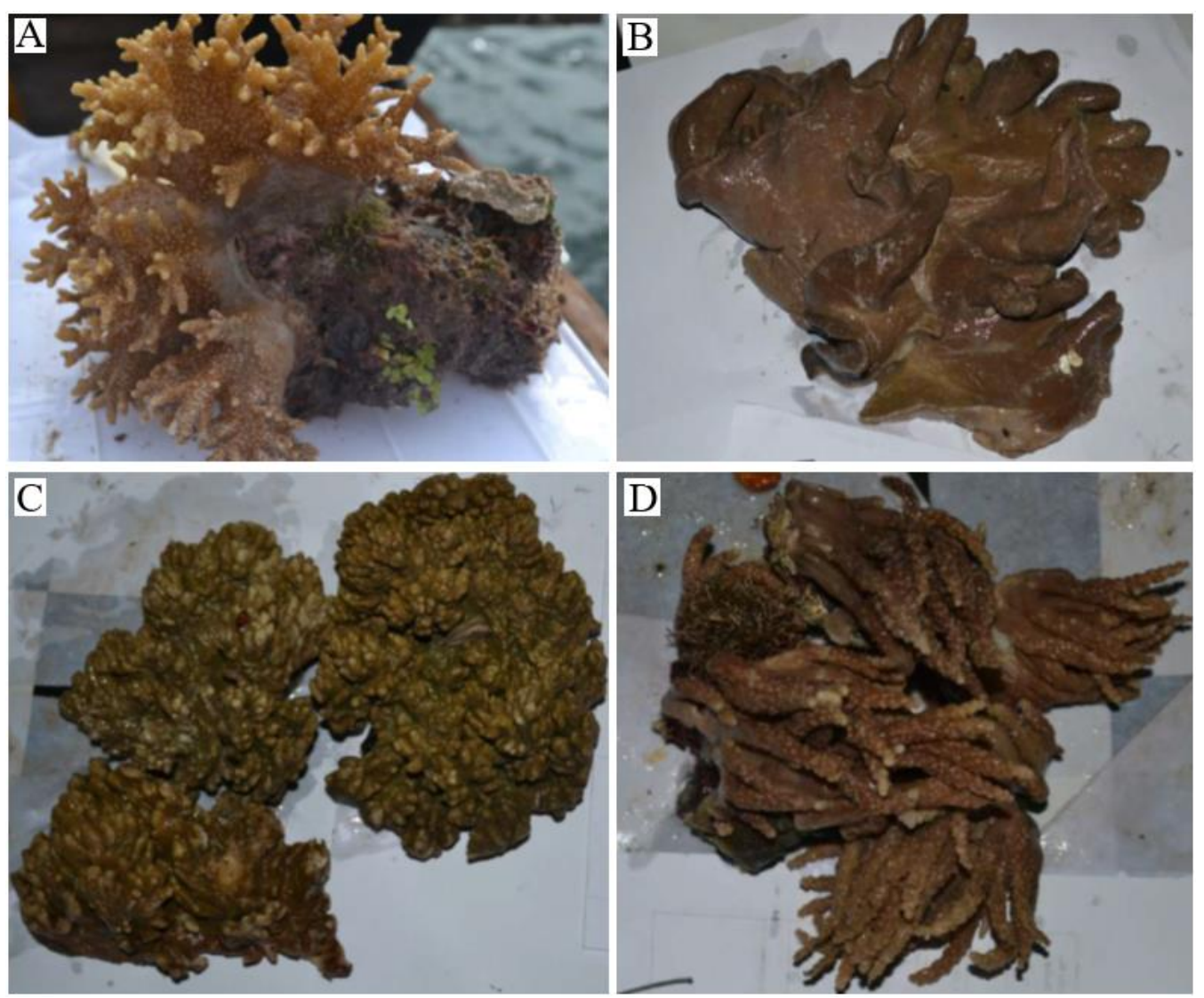

Figure 1. Soft corals collected from Togean Islands. A: Lobophytum sp, B:Sarcophyton sp, C: Sinularia sp 1, D: Sinularia sp 2

highest diameter of inhibition zone of $15.80 \pm 0.30 \mathrm{~mm}$ and $15.73 \pm 0.41 \mathrm{~mm}$, followed by Sarcophyton sp and Sinularia sp 1. Lobophytum sp did not possess the inhibition on $S$. aureus and E. coli.

The cytotoxic activity on human colon carcinoma (HCT-116) of soft corals extracts, found that Sinularia sp 1 methanolic extract have time dependent potent cytotoxicity at 24 and $48 \mathrm{~h}$ with the $\mathrm{IC}_{\text {s }}$ of 1.505 and $<1.505 \mu \mathrm{g} / \mathrm{mL}$, respectively (Table II). Moreover, it is also showed cytotoxicity on MCF-7 with the IC $C_{\approx}$ of $24.02 \mu \mathrm{g} / \mathrm{mL}$ after $48 \mathrm{~h}$ incubation. Sinularia sp 2 extract can be categorized also to have potent cytotoxicity on HCT-116 and MCF-7 where the IC 50 of 46.807 and $47.186 \mu \mathrm{g} / \mathrm{mL}$, respectively. Sinularia sp 2 extract showed high selectivity on cell growth inhibition where it is found to be not toxic on both CCD and NHDF normal cells.
Meanwhile, Sinularia sp 1 found not selective as it has toxicity to both CDD and NHDF normal cells. Further identification of the possible apoptosis mechanism of the potential extracts of Sinularia sp 1 and Sinularia sp 2 was done by Annexin V-FITC assay. The result showed that methanolic extract of Sinularia sp 1 and Sinularia $s p 2$ have significant percentage of early and late apoptosis with the value of $51.90 \%$ and $42.90 \%$ on MCF-7 and $51.20 \%$ and $49.60 \%$ on HCT116 cell lines, respectively (Figure 2 )

Sinularia has been commonly known to contain class of terpenoid compounds that possessing broad antimicrobial and potent cytotxicity activity. For example, a casbane diterpenes called 10-hydroxydepressin from Sinularia depressa, inhibit S.aureus and E.coli at 17 $\mu \mathrm{M}$ and possess cytotoxic on HepG2 and SW1990 with the IC 50 of 61 and $37 \mathrm{uM}$, respectively (Li et al., 2010), sinulariolide and flexibilide 

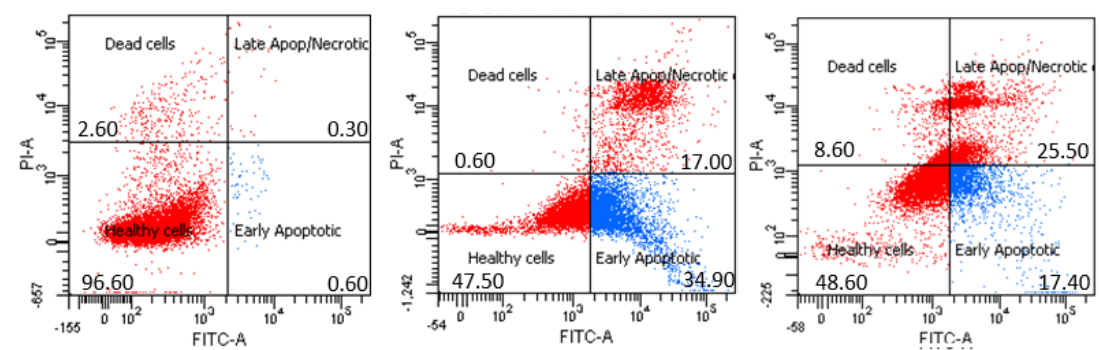

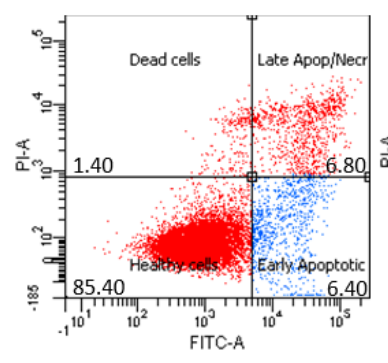

A

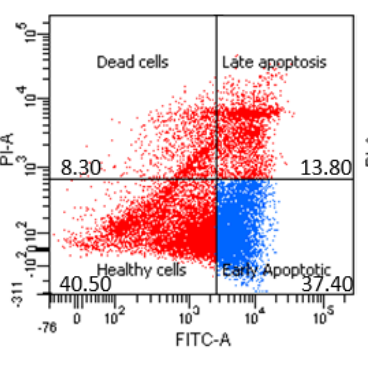

B

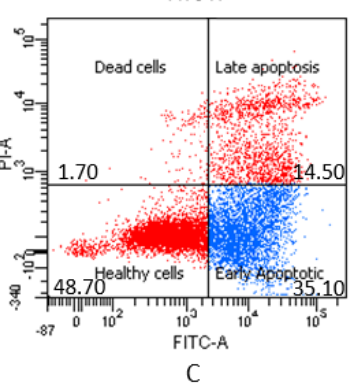

Figure 2. Effect of Untreated (A), Sinularia sp 1 (B) and Sinularia sp 2 (C) methanolic extract on MCF-7 (Above) and HCT-116 (Below) on annexin V-FITC-positive staining. The four quadrants identified as LL (healthy cells); LR (early apoptotic); UR (late apoptotic) and UL (necrotic).

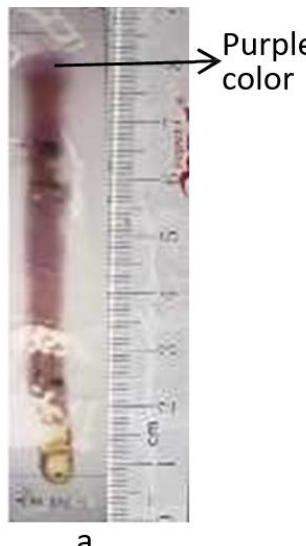

a
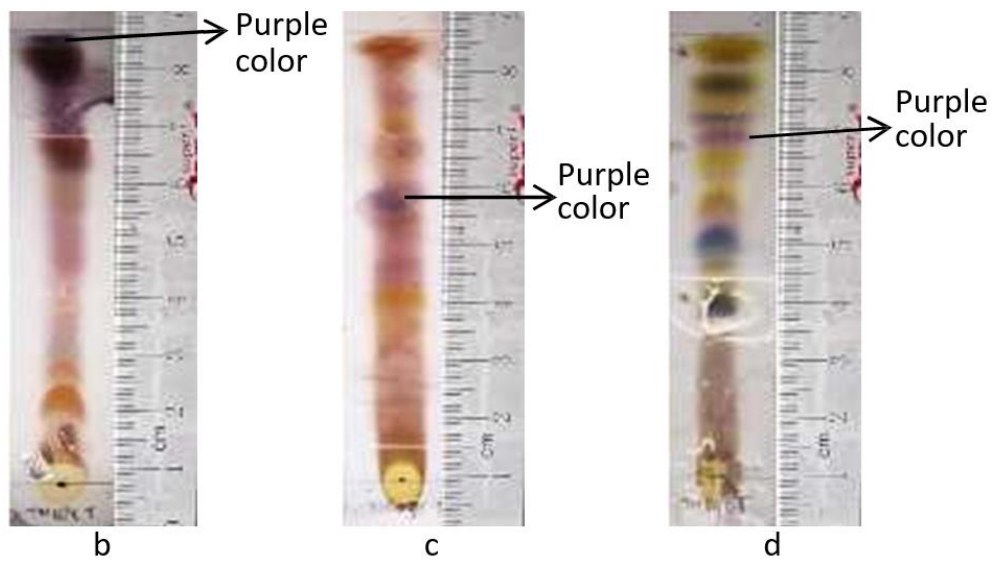

Figure 3. TLC Identification using p-anisaldehyde-sulphuric acid of the extract Lobophytum sp (a), Sarcophyton sp (b), Sinularia sp 1 (c), dan Sinularia sp 2 (d)

from $S$ flexibilis, exhibited growth inhibition of gram-positive bacteria. at concentrations of 10 and 5 ppm, respectively (Aceret $e$ t al., 1998). A new cembrenolid diterpene isolated from the hybrid softcoral Sinularia maxima and $S$. polydactyla showed strong cytotoxicity on the breast cancer SK-BR3 cell line and cervix cancer HeLa and HeLa-Apl cell lines with $\mathrm{GI}_{50}$ values of $0.039,0.48$, and $0.56 \mathrm{mM}$, respectively (Kamel et al., 2007). Flexilarins D isolated from S. flexibilis exhibited potent cytotoxicity against
Hep G2 tumor cells with an $\mathrm{ED}_{50}$ value of $0.07 \mathrm{ug} / \mathrm{mL}$ (Lin et al., 2009). Based on these studies, we further identify terpenoids content on the extract. Identification was done by thin layer chromatography using anisaldehydesulphuric spraying reagent (Figure 3). It is clearly shown that Sinularia sp 1 and Sinularia $s p$ 2 extracts are possible to contains terpenoids as they shown one spot (purple color after spraying) that means positive for terpenoids. 


\section{CONCLUSION}

Sinularia sp 2 is the most potential extract that has broad spectrum of antibacterial activity and potent cytotoxic activity. Moreover, it selectively inhibited MCF-7 and HCT-116 and less toxic to normal cells. Meanwhile, Sinularia sp 1 showed potent cytotoxicity on all cell line studied and more toxic on normal cells compare to Sinularia sp 2. Apoptosis mechanism were proposed as mechanism of Sinularia sp 1 and Sinularia sp 2 extracts. The presence of terpenoids suggested them as bioactive compounds of soft corals. It is needed for further isolation and purification of these terpenoid compounds

\section{ACKNOWLEDGEMENT}

Authors would like to acknowledge the Ministry of Research, Technology and Higher Education, Republic of Indonesia, for financial support via Postdoctoral Research Grant (285/UN28.2/PL/2018).

\section{REFERENCES}

Abou El-Ezz RF., Ahmed SA., Radwan MM., Ayoub NA., Afifi MS., et al., 2013. Bioactive cembranoids from the Red Sea soft coral Sarcophyton glaucum, Tetrabedron Lett. 54: 989-992.

Aceret TL., Coll JC., Uchio Y., Sammarco PW. 1998. Antimicrobial activity of the diterpenes flexibilide and sinulariolide derived from Sinularia flexibilis Quoy and Gaimard 1833 (Coelenterata: Alcyonacea, Octocorallia). Comp Biochem Physiol C Pharmacol Toxicol Endocrinol. 120(1): 121-126.

Afifi R., Abdel-Nabi IM., El-Shaikh K. 2016. Antibacterial activity from soft corals of the Red Sea, Saudi Arabia. I Taibah Univ Sci. 10(6): 887-895.

Al-Footy KO., Alarif WM., Zubair MS., Mohamed A., Aly MM. 2016. Antibacterial and cytotoxic properties of isoprenoids from the red sea soft coral Lobophytum sp, Trop I Pharm Res. 15(7): 1431-1438.
Blunt JW., Copp BR., Munro MHG., Northcote PT, Prinsep MR. 2016. Marine natural products. Nat Prod Rep. 27(2):165-237. doi:10.1039/b906091j

Chen W., Li Y., Guo Y. 2012. Terpenoids of Sinularia soft corals: chemistry and bioactivity. Acta Pharm Sin B. 2(3):227237. doi:10.1016/j.apsb.2012.04.004

Coll JC. 1992. The chemistry and chemical ecology of octocorals(Coelenterata, Anthozoa, Octocorallia), Chem. Rev. 92: 613-631.

Kamel HN., Ferreira D., Garcia-Fernandez LF., Slattery M. 2007. Cytotoxic diterpenoids from the hybrid softcoral Sinularia maxima x Sinularia polydactyla. J Nat Prod. 70: 1223-1227.

Li Y., Carbone M., Vitale RM., Amodeo P., Castelluccio F., Sicilia G., et al. 2010. Rare casbane diterpenoids from the Hainan soft coral Sinularia depressa. J Nat Prod. 73: 133-138.

Limberger RP., Sobral MEG., Zuanazzi JAS., Moreno PRH, Schapoval EES. 2001. Biological activities and essential oil composition of leaves of Blepharoclyx salicifolius. Pharm Biol. 39(4): 308-311.

Lin YS., Chen CH., Liaw CC., Chen YC., Kuo YH., et al. 2009. Cembrane diterpenoids from the Taiwanese soft coral Sinularia flexibilis. Tetrabedron. 65: 9157-9164.

Putra MY., Wibowo JT., Murniasih T., Rasyid A. 2016. Evaluation of antibacterial activity from Indonesian marine soft coral Sinularia sp. AIP Conf Proc. 1744. doi:10.1063/1.4953513

Zubair M., Alarif W., Al-Footy K., PH Mohamed., Ali M., et al. 2016. New antimicrobial biscembrane hydrocarbon and cembranoid diterpenes from the soft coral Sarcophyton trocheliophorum. Turk J Chem. 2016: 40; 385-392

Zubair MS., Anam S., Lallo S. 2016. Cytotoxic activity and phytochemical standardization of Lunasia amara Blanco wood extract. Asian Pac J Tropical Biomed. 6(11): 962-966. 